\title{
Selective serotonin-reuptake inhibitor and norepinephrine dopamine reuptake inhibitor antidepressants do not affect natural killer cell activity in vitro
}

Antidepressivos inibidores seletivos de recaptação da serotonina e inibidores da recaptação de noradrenalina e dopamina não afetam a atividade celular natural killer in vitro

Gabriel J. Chittó Gauer', Vivian M. Rumjanek2, Sebastião Francisco Costa², Ramiro Ronchetti', Rachel Rubin da Silva', Leonardo M. da Silva'

\section{RESUMO}

Objetivo: Avaliar o efeito citotóxico de dois antidepressivos comumente utilizados na prática, a paroxetina e a bupropriona. Além disso, buscou-se avaliar a atividade natural killer (ANK) após a incubação dos linfócitos com esses fármacos. Métodos: Sangue venoso de 15 participantes foi coletado e as células mononucleares (PBMCs) foram separadas e

\section{Palavras-chave}

Atividade natural killer, antidepressivos, sistema imune, psicoimunologia, psicofarmacologia, toxicidade medicamentosa.

\section{Keywords}

Natural killer activity, antidepressants, immune system, psychoimmunology, psychopharmacology, drug toxicity. incubadas por $24 \mathrm{~h}$ com (ou sem = grupo-controle) concentrações de paroxetina e bupropiona em 30, 100 e $1.000 \mathrm{ng} / \mathrm{ml}$. Após a incubação, a quantidade das células mortas foi contada utilizando-se o método trypan blue. Posteriormente foi avaliada a ANK por meio do ensaio clássico de liberação do $\mathrm{Cr}^{51}$. Conclusões: Ocorreu morte celular de PBMCs proporcionais às doses dos fármacos, no entanto, a ANK não foi afetada, mesmo com a redução do número de células efetoras.

\section{ABSTRACT}

Objective: This study aims to evaluate the citotoxic activity of two commonly used anti-depressants: paroxetine and bupropion. We also evaluated the in vitro natural killer activity (NKA) after incubating the blood samples with the antidepressants. Methods: Peripheral blood samples from 15 healthy volunteers were collected and the mononuclear cells (PBMCs) were isolated and incubated for $24 \mathrm{~h}$ with (or without = control cells) paroxetine and bupropion, in concentrations of 30,100 and $1000 \mathrm{ng} / \mathrm{ml}$. After the incubation period in both groups, the amount of dead cells was calculated using trypam blue technique. NKA was evaluated using the classic ${ }^{51} \mathrm{Cr}$ release assay. Conclusions: PBMCs dead cells occurred in both groups and in proportion to all pharmacological concentrations. Nevertheless, the NKA was not affected, even with the reduction in the number of effective cells.

1 Pontifícia Universidade Católica do Rio Grande do Sul (PUC-RS).

2 Universidade Federal do Rio de Janeiro (UFRJ), Instituto de Bioquímica Médica. 


\section{INTRODUCTION}

The relation between depressive episodes and changes in the IS is clear in clinical practice. There are two aspects to be considered here: immune responses are blunted in cases of severe depression' or cytokine treatments can cause symptoms of depression in patients with no previous history of mental disorders ${ }^{2}$.

A study of the cerebral distribution of serotonin transporters $(5 \mathrm{HT})^{3}$, also found in IS cells, showed high concentration of $5 \mathrm{HT}$ in areas of the amygdala, thalamus, hypothalamus, substantia nigra, hippocampus, locus ceruleus and raphei nuclei - structure of serotonergic neurons ${ }^{4}$. It seems that in lymphocytes 5-HT it has immunomodulatory properties. Some authors suggested that the immunomodulatory role of SSRI is originated from the direct action on lymphoid cells.

Paroxetine, for instance, is one well known and widely used drug for the treatment of major depression, anxiety disorder and post-traumatic stress disorder ${ }^{6}$. Some studies have demonstrated stimulating effects on peripheral leukocytes? whereas others found no significant changes ${ }^{8}$. Other studies that investigated the role of medications other than SSRIs, usually involved antidepressants with some kind of serotonergic activity such as venlafaxine and mirtazapine ${ }^{8,9}$. Bupropion is an antidepressant drug with a unique mechanism of action: it has noradrenergic and dopaminergic (NDRI) activity with no clinically significant effects on serotonin reuptake ${ }^{10}$. Except for some controversial discussion about the role of bupropion in the pathogenesis of medical conditions with immunological features (e.g. erythema multiform) $)^{11,12}$, no investigations have been made to elucidate the immunological effects of bupropion in healthy individuals.

Tricyclic antidepressants (TCA) like imipramine, that act upon both the noradrenergic and the serotonergic systems jeopardize the immune system, and that, conversely, ISSR like paroxetine improve it, raised an important question. In order to contribute to answer this question we decided to evaluate separately the effect in the IS of a drug with only serotonergic activity (paroxetine) and a drug with only noradrenergic/dopaminergic activity (bupropion) ${ }^{13}$. As we had the results regarding the activity of both drugs on lymphocyte proliferation ${ }^{15}$ we decided to examine their citotoxicity and NKA action.

\section{METHOD}

\section{Subjects}

Fifteen healthy young adults (20-40 yrs; 6 females), university students were selected for subsequent analysis. A psychiatric and a physical examination was performed. Individuals suffering from mental disorder or any disease (as well as history of), and those individuals in current use of medication, except for oral contraceptives, were excluded.

\section{Procedures in vitro}

\section{Incubation with mononuclear cells}

Peripheral blood $20 \mathrm{ml}$ samples were collected from 15 normal volunteer and mononuclear cells were isolated by centrifugation over a Ficoll-Hypaque gradient (Sigma, St. Louis, MO USA). Peripheral blood mononuclear cells (PBMC) were ressuspended at a concentration of $5 \times 10^{6}$ cells $/ \mathrm{ml}$ in RPMI1640 culture medium (Sigma), supplemented with penicillin $1 \%$, streptomycin $1 \%$, with $10 \%$ fetal calf serum (FCS - Gibco). Paroxetine and bupropion were dissolved in distilled water and diluted to concentrations of 25, 100 and $1000 \mathrm{ng} /$ $\mathrm{ml}$ in RPMI with $10 \%$ FCS. Mononuclear cells were incubated for $24 \mathrm{~h}$ at $37^{\circ}$ and $5 \% \mathrm{CO}_{2^{\prime}}$ in culture flasks, with the different concentrations of paroxetine or bupropion. After the incubation period, the amount of dead cells, incubated or not with the drugs, was calculated using trypan blue. The cell suspension resulting was adjusted to a final concentration of $5 \times 10^{6} / \mathrm{ml}$ viable cells. Control cells were incubated under identical conditions without drugs. After the incubation period the cells that survived were washed, resuspended in RPMI with $10 \%$ FCS, serially diluted in a microtiter plate, and assessed for cytotoxic activity using the ${ }^{51} \mathrm{Cr}$ release assay as described below.

\section{Natural killer activity assay}

The NKA was assayed in a standard ${ }^{51} \mathrm{Cr}$ release assay, using as target the K562 human erythroleukemia derived cell line. Viability of target cells exceeded $95 \%$, as judged from their ability to exclude trypan blue. Mononuclear effector cells were adjusted to $5 \times 10^{6}$ cells $/ \mathrm{ml}$ viable cells. K562 target cells were labelled with $150 \mu \mathrm{Ci}$ of $\mathrm{Na}^{51} \mathrm{CrO}_{4}$ (IPEN-CENEN, São Paulo, Brazil) for $2 \mathrm{~h}$ at $37^{\circ} \mathrm{C}$ and $5 \%$ de $\mathrm{CO}_{2^{\prime}}$ washed and adjusted to $5 \times 10^{4} \mathrm{cell} / \mathrm{s} / \mathrm{ml}$ in RPMI and $10 \% \mathrm{FCS}$. Cells were plated (using V-bottom microplates) in triplicate with several effector-target ratios (100:1, 50:1, 25:1, and 12:1) and incubated at $37^{\circ} \mathrm{C}$ in $5 \% \mathrm{CO}_{2}$ for 4 hours. Aliquots $(100 \mu \mathrm{l}$ of supernatant) were analysed in a $\mathrm{Y}$-counter and percent of specific lysis was determined according to the formula:

$\%$ of Lysis $=100 \times$ Experimental release $(\mathrm{cpm})-$ Spontaneous release $(\mathrm{cpm})$

Total (cpm) - Spontaneous release (cpm)

The mean specific release for the three optimum effector-target cell ratios was utilized as the unit of measurement of NKA.

\section{Statistical analysis}

NKA results were analyzed by ANOVA for repeated measures with post hoc analyses. A difference was considered 
statistically significant when $p<0.05$. All statistical analyses were performed with the statistical software SPSS/PC 12 (Chicago, EUA).

\section{Ethics considerations}

The individuals who agreed to participate in the project read and signed an informed consent term. The project was approved by the Ethics Committee in Research of the Pontifícia Universidade Católica do Rio Grande do Sul (CEP/PUCRS n. 646/05) (July 25, 2005).

\section{RESULTS}

\section{Bupropion}

Analyzing the amount of dead cells using the ANOVA for repeated measures, there was a statistical difference related to the concentration of the drug. The number of cells from the control group $\left(\right.$ mean $\left.=4.90 \times 10^{6} ; \mathrm{SD}=0.52 \times 10^{6}\right)$ was different from the number of cells on the bupropion group in the concentration of $30 \mathrm{ng} / \mathrm{ml}$ (mean $=4.15 \times 10^{6} ; \mathrm{SD}=$ $\left.0.46 \times 10^{6}\right) ; 100 \mathrm{ng} / \mathrm{ml}\left(\right.$ mean $\left.=3.60 \times 10^{6} ; \mathrm{SD}=0.35 \times 10^{6}\right)$ and $1000 \mathrm{ng} / \mathrm{ml}\left(\right.$ mean $\left.=2.77 \times 10^{6} ; \mathrm{SD}=0.59 \times 10^{6}\right)$. There was a significant difference in direction of a lower number of cells in all the concentrations at the bupropion group when compared to the control $(p<0.001)$.

Regarding the NKA comparing all concentration levels of bupropion (i.e., 30 ng; 100 ng; 1000 ng/ml), accordingly to the ANOVA for repeated measures analysis there was no difference in the lytic activity between control lymphocytes and lymphocytes pre-incubated with bupropion ( $p=0.260$ ).

\section{Paroxetine}

Regarding the amount of dead cells the ANOVA for repeated measures analysis showed no statistical difference between the number of cells at the control group (mean $=4.82 \times 10^{6}$; $\left.\mathrm{SD}=0.48 \times 10^{6}\right)$ and cells incubated with paroxetine at 30 $\mathrm{ng} / \mathrm{ml}\left(\right.$ mean $\left.=4.46 \times 10^{6} ; \mathrm{SD}=0.35 \times 10^{6}\right)$. However there was a difference when the control group cell number was compared to the number of cells on the paroxetine group using the concentration of $100 \mathrm{ng} / \mathrm{ml}$ (mean $=3.70 \times 10^{6}$; $\left.\mathrm{SD}=0.36 \times 10^{6}\right)$ or $1000 \mathrm{ng} / \mathrm{ml}\left(\right.$ mean $=2.43 \times 10^{6} ; \mathrm{SD}=0.47$ $x 10^{6}$ ). There was a significant difference in the direction of a lower number of cells in the concentrations of $100 \mathrm{ng} / \mathrm{ml}$ and $1000 \mathrm{ng} / \mathrm{ml}$ at paroxetine group when compared to the control $(p<0.004)$.

Comparing the NKA at all concentration levels of paroxetine (ie., 30 ng; 100 ng; 1000 ng/ml), there was no difference in the lytic activity between control lymphocytes and lymphocytes pre-incubated with paroxetine $(p=0.128)$.

\section{DISCUSSION}

Despite the fact that pre-incubation with paroxetine and bupropion produced, in vitro, a clear toxic effect in PBMC, even when concentrations were higher than therapeutic plasma levels $(1000 \mathrm{ng} / \mathrm{ml})$, the ability of the remaining viable cells to kill the eritroleukemic K562 tumor cells was not affected. Because these drugs present serotonergic and noradrenergic action, these findings suggest that their action on these systems are probably not related to NKA inhibition. These results suggest that the blunted NKA and lymphocyte proliferation seen with TCA might be related to their action on other receptors such as the histaminergics or cholinergic ones. Another hypothesis is that such effects result from a direct action of those old medicines molecules over the IS. It is possible that these two new agents do not have such intrinsic property.

Some studies reported that paroxetine had stimulatory effects on peripheral leukocytes ${ }^{7}$ whereas others showed no significant changes ${ }^{9}$. One aspect to be considered is that the lack of response in our study could be due to the fact that the cells examined were obtained from healthy individuals, supposedly without alterations in $5 \mathrm{HT}$ transporters ${ }^{14}$. It is worth mentioning that even in depressed patients the paroxetine may not have the immunological effects if it is not paralleled by clinical changes. There is also a greater probability of finding changes in lymphocyte $5 \mathrm{HT}$ transporters in patients with severe depression, melancholy and associated clinical co morbidities ${ }^{1,2}$. Furthermore, another study reported for the fist time that bubropion has no effect on lymphocyte proliferation ${ }^{15}$ and, in the present study, cells pre-treated with bupropion maintained NK activity. Previous studies observed a tendency for improvement of the immune response with the administration of other double action antidepressants, with at least some serotonin action (mirtazapin) ${ }^{9}$

\section{CONCLUSION}

Despite the limitations of this study (small sample and there was no comparison between the results of these ADs with other drugs), paroxetine and buproprion didn't seem to affect the NKA in any of the plasma concentrations, even in doses much higher than the recommended practice. The present findings show that these drugs have a toxic effect for the PBMCs but they seem not to interfere in the NKA. So, they might have a more favorable effect on the immune system, specially when we compare the results with others described in the literature with older agents, such as the tricyclics ADs. 


\section{REFERENCES}

1. Zorrilla EP, McKay JR, Luborsky L, Schimidt K. Relation of stressors and depressive symptoms to clinical progression of viral illness. Am J Psychiatry. 1996;153(5):626-35.

2. Musselman DL, Lawson DH, Gumnick JF, Manatunga AK, Penna S, Goodkin RS, et al. Paroxetine for the prevention of depression induced by high-dose of interferon alfa. NEJM. 2001;344:961.

3. Barker EL, Blakely RD. Norepinephrine and serotonin transporters. Molecular targets of antidepressant drugs. In: Bloom FE, Kupfer DF (ed.). Psychopharmacology: the fourth generation of progress. New York: Raven Press; 1995.

4. Owens MJ, Nemeroff CB. Role of serotonin in the pathophysiology of depression: focus on the serotonin transporter. Clin Chem. 1994;40(2):288-95.

5. Lima L, Urbina M. Serotonin transporter modulation in blood lymphocytes from patients with major depression. Cell Mol Neurobiology. 2002;22(5-6):797-804.

6. Bezchlibnyk-Butler KZ, Jeffries JJ, Virani AS (eds.). Clinical handbook of psychotropic drugs. 17.ed. Ashland: Hogrefe \& Huber Publishers; 2007.

7. Iga J, Ueno S, Yamauchi K, Motoki I, Sumiko T, Koshi 0, et al. Serotonin transporter mRNA expression in peripheral leukocytes of patients with major depression before and after treatment with paroxetine. Neurosci Lett. 2005;389(1):12-6.
8. Denys D, Fluitman S, Kavelaars A, Heijnnen C, Westenberg HG. Effects of paroxetine and venlafaxine on immune parameters in patients with obsessive compulsive disorder. Psychoneuroendocrinology. 2006;31(3):355-60.

9. Pena S, Bacichet E, Carreira I, Lima L. Effect of mirtazapine treatment on serotonin transporter in blood peripheral lymphocytes of major depression patients. Int Immunopharmacol. 2005;5(6):1069-76.

10. Bakish D. New standard of depression treatment: remission and full recovery. J Clin Psychiatry. 2001;26:5-9.

11. Carrillo-Jimenez R, Zogby M, Treadwell TL. Erythema multiforme associated with bupropion use. Arch Int Med. 2001;161(12):1556.

12. Drago F, Rebora A. Is erythema multiforme associated with bupropion use? Arch Int Med. 1998;162(7):843.

13. Gauer GJC, Rumjanek V, Lazzari A. Fármacos antidepressivos e imunidade. Rev Psiquiatria Rio Grande do Sul. 1998;20(49):54.

14. Cruess DG, Douglas SD, Petitto J, Have TT, Gettes D, Dube B, et al. Association of resolution of major depression with increased natural killer cell activity among HIV-seropositive women. Am J Psychiatry. 2005;162(11):2125-30.

15. Ronchetti R, Dal Pizzol M, Lopes RP, Silva RR, Gauer GJC, Bauer ME. Paroxetine and bupropion have no in vitro effects on lymphocyte proliferation and viability. J Bras Psiquiatria. 2007:56(2):116-9. 